\title{
Limited, inclusive, and communitarian: in defence of recognising property in the human body
}

\author{
NeIL MAdDOX*
}

Maynooth University

\begin{abstract}
While recognising property in the buman body would have its uses, there are objections to granting such rights given the unique nature of the body. One objection is that property serves individualistic and not communitarian values and fails to capture the body's relational interdependent nature. I contest this objection as it takes an overly narrow view of property as being 'Blackstonian' in character, eliding the diversity of property institutions that actually exist. Thus, the usefulness of property law in the protection and management of community resources and the manner in which property is often limited by non-property interests that the law is accustomed to protecting have not been accounted for. I contend that property facilitates cooperative buman activity and could potentially provide useful tools for the protection of individual and communal rights in the body. I further contend that, where property rights have tentatively been recognised in buman biomaterials, they are not strongly exclusive in character and are consistent with property's inclusive and communitarian nature in being limited to prevent public barm and by reference to the non-property interests of other persons and the community.
\end{abstract}

Keywords: Blackstone; the body; ownership; property; personhood; tissue

\section{Introduction}

W hether the interests of the person in their body and its parts and products should be protected by the recognition of property rights vesting in the source of these materials (whereby a person may acquire property rights in their own bodily materials), or alternatively, through other non-property legal mechanisms, remains a highly contested area of debate. ${ }^{1}$ Leaving aside momentarily the objections to this approach, there are a number of advantages of adopting the property paradigm in order to protect the rights and interests

* The author would like to thank Professor Colin Gavaghan of the Centre of Law and Emerging Technologies at the University of Otago, New Zealand, and Professor Karinne Ludlow of Monash University Law Faculty, Melbourne, Australia, for hosting the author during the research sabbatical in which the work for this piece was carried out.

1 See the discussion in I Goold, K Greasley, J Herring and L Skene (eds), Persons, Parts and Property: How Should We Regulate Human Tissue in the 21st Century? (Hart 2014); R Hardcastle, Law and the Human Body: Property Rights, Ownership and Control (Hart 2007); R N Nwabueze, Biotechnology and the Challenge of Property: Property Rights in Dead Bodies, Body Parts and Genetic Information (Ashgate 2007); J Wall, Being and Owning: The Body, Bodily Material and the Law (Oxford University Press 2015). M Quigley, Self-Ownership, Property Rights and the Human Body: A Legal and Philosophical Analysis (Cambridge University Press 2018). 
of persons in their body. ${ }^{2}$ Of particular usefulness to judges facing novel and difficult questions relating to the control and use of the body and its parts is that property provides remedies in cases where none would otherwise be available. ${ }^{3}$ Granting such a strong right as a property right to the source of such materials could provide a valuable tool in protecting the dignity and autonomy of the person by enabling them to control how their bodily products are used and would provide a valuable counterweight to commercial interests that would seek to instrumentalise the body and its parts for private gain, without recourse to or concern for the source of those biomaterials. ${ }^{4}$

Nevertheless, there are concerns with treating the human body as property. ${ }^{5}$ There are principled concerns; for example, that property would lead to the commodification of human beings and their parts and this would constitute an affront to human dignity. ${ }^{6}$ There are also practical objections, one of which states that allowing the source of human tissue a property right in it would unduly fetter medical research. ${ }^{7}$

There is a broader objection to the use of property which I contest in this article. This asserts that property models are largely underpinned by individualistic values and merely protect exclusion and control. Under this objection, the adoption of a property model to regulate the uses of the body and its parts serves to characterise it as 'bounded and selfcontained'. This misrepresents the true nature of the body which is inherently relational. ${ }^{8}$ In this article, I contend that this objection to adopting a property model for regulating human biomaterials is rooted in the assumption that property is adequately described by William Blackstone's ownership model (recently rehabilitated as exclusion), ignoring the fact that property is often much more limited and inclusive than that conceived by Blackstone and his successors.

I also examine the recent work of a number of legal pluralists who contend that property should be understood as a mode of organising social relationships, that property owners have not just rights but obligations towards other owners, non-owners and the community as a whole. ${ }^{9}$ I show that the recognition of property rights in human biomaterials is developing more in accordance with this view of property. Accordingly, where property rights have been so recognised in human biomaterials, they have been limited by the protection of non-property interests in a way that would be predicted by legal pluralists, but could not be accounted for by those who adhere to accounts of property as an institution being synonymous with full-liberal ownership and exclusively serving individualistic values.

2 As described by L Skene, 'Raising Issues with a Property Law Approach' in Goold et al (n 1) 263-69, 266.

3 For example, in Yearworth v North Bristol NHS Trust [2009] EWCA Civ 37, the loss of frozen sperm samples was deemed compensable as damage consequent on property damage by recognising the frozen sperm as property.

4 L Skene, 'Arguments Against People Legally “Owning” their Own Bodies' (2002) 2 Macquarie Law Journal 165.

5 Ibid.

6 J W Harris, Property and Justice (Oxford University Press 1996) 351-52.

7 Moore $v$ Regents of the University of California (1990) 51 Cal 3d 120, [4a].

8 J Herring, 'Why We Need a Statute Regime to Regulate Bodily Material' in Goold et al (n 1) 215, $216-223$.

9 J W Singer, The Paradoxes of Property (Yale University Press 2000); H Dagan, Property: Values and Institutions (Oxford University Press 2011); G S Alexander, 'Pluralism and Property' (2011) 80 Fordham Law Review 1017. 


\section{The objection: property serves individualistic values whereas the body is relational}

A number of commentators object to property in the body on the basis that it serves the values underpinning autonomy and the market that are atomistic, self-focused and competitive. These principles are at variance with the broader range of values that we should seek to promote when dealing with questions concerning the body, its parts and products. Thus, property rights, it is claimed, would objectify the body as bounded and self-contained when its true nature is in fact relational and interdependent. An understanding of the self as individualised means personhood is then presented by reference to abilities which are self-referential and emphasise independence, and the kinds of ethical values that are said to be advanced by individualised concepts of the self are autonomy, freedom and liberty. ${ }^{10}$ Accordingly, there is a presumption that such freedoms should not be interfered with unless sufficient justification can be produced. The role of law becomes primarily to keep others out and leave the person free to carry on activities of their choosing as they wish. ${ }^{11}$

In allowing its owner to be the supreme agenda-setter in respect of a resource, property rights are seen to protect only one set of legal interests: those of control, exclusion and transfer with proceedings rarely being brought on behalf of communal interests. ${ }^{12}$ In this view, conceiving of the body as property leads to the attitude that it is a thing controlled by the self with which one can do what one wants. Accordingly, individuals should have control of their bodies and body parts and no one else can have ownership of them. ${ }^{13}$ Furthermore, it is the individual who determines the appropriate use of body parts and they should be able to deal with them as they wish. ${ }^{14}$

This line of criticism also asserts that the favouring of individualistic interests inherent in property institutions treats the body as atomised when its true nature is relational. Bodies are 'leaky' in the sense that the meaning and understanding of the self is not easily captured by one concept or approach. ${ }^{15}$ This view of the self sees it as having definition and moral value in its relation to others and our relationship with them. In contrast to the role of law in the individualised conception, which seeks to keep people apart, the relational approach sees the purpose of law as enabling good relationships and caring relationships to thrive. ${ }^{16}$ This approach does not view the body as a controlled and independent entity. Rather, it emphasises the interconnectedness and interdependence of bodies. This connectedness is to other bodies, such as during pregnancy or through genetics. ${ }^{17}$ Human dependence and interdependence are natural parts of the human condition through birth, aging, sickness and the need for companionship. ${ }^{18}$ This all means that it is impossible to consider our bodies separate from other bodies. My body

10 J Herring and P-L Chau, 'Relational Bodies' (2013) 21 Journal of Law and Medicine 294, 294.

11 Ibid 295

12 Herring (n 8) 216. Herring cites Larissa Katz, an exclusion theorist of property, as authority for an owner's agenda-setting powers over their resource: L Katz, 'Exclusion and Exclusivity in Property Law' (2008) 58 University of Toronto Law Journal 275.

13 Herring and Chau (n 10) 295.

14 Ibid.

15 J Herring and P L Chau, 'My Body, Your Body, Our Bodies' (2007) 15 Medical Law Review 34, at 60, quoting Margrit Shildrick, Leaky Bodies and Boundaries: Feminism, Postmodernism and (Bio) Ethics (Routledge 1997).

16 Herring and Chau (n 10) 295.

17 Herring and Chau (n 15) 45-49.

18 T Levi, 'The Relational Self and the Right to Give Care' (2006) 28 New Political Science 547, 548. 
is not thus 'mine' in a straightforward manner, and the individualistic values of control and exclusion promoted by property can never fully capture it.

The fact that a variety of forms of property may exist does not overcome the objection on this view of property. While obviously not all types of property are unqualified, exclusive and individualistic, these attributes are the 'starting presuppositions' of property. ${ }^{19}$ Thus, there is a presumption that absolute and unqualified ownership is the norm. And, while proponents of property point to its technical capacity to encompass exceptions, qualifications and regulations to adapt it to a particular purpose, these must be justified in each case as such limits deviate from the normal conception of what property is. So, property as a legal tool forces us to divert energy into constantly justifying any limits on its absolute nature, as such limits are regarded as aberrant and contrary to what property truly is. ${ }^{20}$ This view admits that a reformed and new conception of property could be worked towards that would conceive of property in relational terms. ${ }^{21}$ However, the prevailing norms of property are currently unreformed and reflect individualistic and market-driven values. ${ }^{22}$ Although the content of property rights is capable of being limited to serve certain values, in such an environment presumptions would favour granting a full suite of property rights in human biomaterials and would thus favour commodification, objectification, exploitation and alienation. ${ }^{23}$ In this context, the power of legal discourse to translate and replace complex ways of describing human relations into simple formulas is seen as particularly troublesome if we are to conceive of the body as property. On this legal construct, it is feared that bodies would only be viewed as related to each other as mere market commodities where matters such as pain and desire are articulated as types of property damage and consumer preference and love reduced to only another type of contract. ${ }^{24}$

One does not have to look far into mainstream property theory to find evidence that the property paradigm promotes such values. Blackstone described the right of property as 'that sole and despotic dominion which one man claims and exercises over the external things of the world, in total exclusion of the rights of any other individual in the universe'. ${ }^{25}$ Blackstone thus asserted that property was an absolute right vested in the individual by natural law in contrast to the Lockean notion that such rights were dependent on society's recognition that the owner had mixed his labour with the property in some way. ${ }^{26}$ Since owners are free to use their property as they wish, we naturally presume that the owner has the fullest amount of powers to use, control, manage and alienate the property, what I will call 'full-liberal ownership'. ${ }^{27}$

Blackstone's 'ownership' model has been modernised by those commentators who reject the 'bundle of rights' picture of property, discussed below, and adopt an exclusion

19 J Nedelsky, 'Property in Potential Life-A Relational Approach to Choosing Legal Categories' (1993) 6 Canadian Journal of Law and Jurisprudence 343, at 353. J Nedelsky, 'Reconceiving Property: Sources, Thoughts and Possibilities' (1989) 1 Yale Journal of Law and Feminism 7.

20 Nedelsky, 'Property in Potential Life' (n 19) 354.

21 Ibid 352-53; R P Petchesky, ‘The Body as Property: A Feminist Revision' in F Ginsburg and R Rapp (eds), Conceiving the New World Order (University of California Press 1995).

22 Nedelsky, 'Property in Potential Life' (n 19) 353.

23 R Rao, 'Property, Privacy, and the Human Body' (2000) 80 Boston University Law Review 359.

24 A Hyde, Bodies of Law (Princeton University Press 1997) 48-49.

25 W Blackstone, Commentaries on the Laws of England (Clarendon Press 1765) ii, *2.

26 R P Burns, 'Blackstone's Theory of the “Absolute” Rights of Property' (1985) 54 Cincinnati Law Review 67.

27 M J Radin, Reinterpreting Property (University of Chicago Press 1983) 100; For a fuller description of 'full-liberal ownership', see J W Harris, Property and Justice (Oxford University Press 2001). 
or boundary approach whereby the essence of property is constituted by the power to exclude all others from the object owned. ${ }^{28}$ It is not then difficult to regard property as promoting individualistic values whereby, by definition, I may exclude the whole world from the resources over which I have dominion, and I may make such use of them as I like without regard for others. It is precisely because of this conception of property institutions as leading to separation, atomisation and selfishness in the use of resources that the appropriateness of the property paradigm being applied to human bodies is challenged. 29

\section{The limits of absolutist and exclusivist accounts of property}

Although undoubtedly influential, the 'ownership' model of property overestimates the extent to which property interests are exclusive and independent of one another and ignores property's relational nature. To characterise property as absolute and exclusive ignores the features of property that facilitate human cooperation and altruism. Indeed, Blackstone accepted that absolute rights may be curtailed by positive law for the blessings of civilised society. ${ }^{30}$ And, notwithstanding the natural law basis of these rights, he acknowledged the functional justifications for property rights within this framework. ${ }^{31}$ The individual is not protected from all government action, only government action that is arbitrary. Indeed, the government in Blackstone's time exercised extensive powers of regulation. ${ }^{32}$ Even in colonial America, where property rights were frequently described in absolutist terms in political rhetoric, these rights were subject to significant regulation and expropriation and property was understood by the colonists as being limited. ${ }^{33}$

While property rights have never been absolute, the rhetoric of absolutism has persisted in political and legal discourse. ${ }^{34}$ This creates a difficulty in that this image of property served to obscure the distinctions between different types of property, for example that the family home deserves a significant degree of legal protection does not mean that a developer's commercial property deserves the same level of protection. ${ }^{35}$ This 'myth of property' emphasises property rights as providing autonomy in the form of independence and this necessarily limits voluntary obligations to others. ${ }^{36}$

A further weakness of these accounts is that exclusion theorists believe the concept of property concerns only relations between owners and non-owners. They are, as one commentator notes, only concerned with the 'external life' of property. ${ }^{37}$ However, the internal life of property, that is the relationships between property stakeholders, is often

28 T Merrill, 'Property and the Right to Exclude' (1998) 77 Nebraska Law Review 730; J Waldron, The Right to Private Property (Clarendon Press 1998) 39; T Merrill and H E Smith, 'What Happened to Property in Law and Economics' (2001) 111 Yale Law Journal 257; K Gray, 'Property in Thin Air' (1991) 50 Cambridge Law Journal 252.

29 J Herring and P-L Chau, 'Interconnected, Inhabited and Insecure: Why Bodies Should not Be Property' (2013) 40 Journal of Medical Ethics 39. Herring and Chau (n 15).

30 Burns (n 26) 73.

31 R A Epstein, 'The Disintegration of Intellectual Property? A Classical Liberal Response to a Premature Obituary' (2010) 62 Stanford Law Review 455, 459.

32 J Williams, 'The Rhetoric of Property' (1998) 83 Iowa Law Review 278, 281.

33 D Schulz, 'Political Theory and Legal History: Conflicting Depictions of Property in the American Political Founding' (1993) 37 American Journal of Legal History 464, 465 and 488-89.

34 Williams (n 32) 280-95.

35 Ibid 294.

36 M C Regan, 'Spouses and Strangers: Divorce Obligations and Property Rhetoric' (1994) 82 Georgetown Law Journal 2303, 2339-59.

37 G Alexander, 'Governance Property’ (2012) 160 University of Pennsylvania Law Review 1853, $1853-54$. 
highly significant to property doctrinally. ${ }^{38}$ Very significant rules regulate, for example, the rights of communities, neighbours, co-owners and families; providing structure for what are cooperative as opposed to competitive relationships. As Carol Rose has observed, we talk about much more when we talk about property, including such things as:

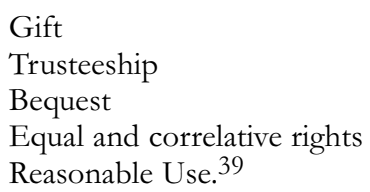

Most of these terms are part of the layperson's understanding of property, and we should not allow the mythology of property - exclusiveness, boundedness and selfishness - to obscure the fact that cooperation and attentiveness to others are essential features of any property law regime. ${ }^{40}$ This 'mythology of property', based as it is on an understanding of property as an antisocial institution, has been used to assert the inappropriateness of applying the language of property to resolve disputes involving intimate human relations. ${ }^{41}$ Nonetheless, while intimate human relationships may be characterised by sharing, nurturing and attentiveness to needs, property and entitlement are inseparable from these features of these relationships. ${ }^{42}$ Indeed, property may be implicit in determining 'who gets what' in the most intimate of settings. 43 On even a cursory examination of how property works, it becomes clear that it is fanciful to regard all its forms as controlled, atomised and independent entities. To identify all property in such terms is to mistake rhetoric for reality and cast to the margins a considerable swathe of property law doctrine that is relational, governing rights between owners (nuisance, easements), between owners and non-owners (licences, public accommodations), in intimate settings (family property), as well as doctrine that ensures the management of property for the benefit of others, or indeed its management in the interests of the public as a whole (private and charitable trusts).

\section{Alternative accounts of property: limited, inclusive and communitarian}

\subsection{PROPERTY AS INCLUSION}

In the view of certain legal pluralists, private law scholars have attempted to provide 'monist' accounts of private law where broad normative accounts suggest that one regulative principle guides the doctrines of complex legal fields. In relation to property, exclusion has been placed at its core by theorists such as Thomas Merrill and Henry Smith and other manifestations of property are pushed to the periphery. ${ }^{4}$ Structural pluralists such as Hanoch Dagan note the tendency for distinct institutions to develop in property law, and the rules for each institution are context-specific with differing rules expressing differing normative commitments in different categories of human

38 Ibid 1855.

39 C M Rose, 'Rhetoric and Romance: A Comment on Spouses and Strangers' (1994) 82 Georgetown Law Journal 2409, 2410.

40 Ibid. The development of 'social norms' theory around property rights heavily emphasises cooperative aspects of neighbourhood relations; R C Ellickson, Order Without Law: How Neighbours Settle Disputes (Harvard University Press1991).

41 Regan (n 36).

42 Rose (n 39).

43 Ibid.

44 Merrill (n 28); Merrill and Smith (n 28); H Dagan, 'Pluralism and Perfectionism in Private Law' (2012) 112 Columbia Law Review 1409, 1410. 
situation. ${ }^{45}$ In this account, each property institution, is 'designed to match the specific balance of values suited to the specific social context' (family, business, etc.). ${ }^{46}$ Not only does conceptualising property as the right to exclude undermine the importance of the internal life of property, it obscures the fact that inclusion is often an important feature of it. ${ }^{47}$ For example, the concept of fair use in copyright law, much of landlord and tenant law and the law of public accommodations involve non-owners' rights of entry that are inherent in property law. ${ }^{48}$ On this view of property, while owners have some rights to exclude others, other values play a crucial role in shaping property institutions and property can and does serve commitments to personhood, desert, aggregate welfare and social responsibility. ${ }^{49}$ The particular configuration of differing entitlements for differing property institutions is not arbitrary or random, but determined by the unique balance of values characterising the property institution. Reshaping property institutions is an on-going process but the ability to repackage rights as envisaged by the HonoréHohfeld conception of property allows judges to develop existing property forms while remaining sensitive to social context. ${ }^{50}$

Indeed, the ownership model fails to acknowledge the frequent conflict between the exercise of property rights and non-property rights. Property rights are not the only rights that matter and are certainly not the only rights protected by the legal system. ${ }^{51}$ Nor should one assume that property rights will prevail in a conflict with personal rights, and conflicts between different legally protected interests means that regulation and limits on private property are far more pervasive than one might assume. ${ }^{52}$ Of particular relevance here is the fact that certain resources may be constitutive of a person's identity resulting in a reconfiguration of property entitlements so that the law vindicates a person's control of their constitutive resources. Margaret Radin supports limiting owners' exclusionary rights in order to protect the personhood interests of others in their property. For example, she espouses residential rent control protection for tenants whose residence is their home and thus constitutive of their person. ${ }^{53}$ The commodification of objects constitutive of personhood is of particular concern, and she contends that there are strong arguments for regarding certain objects, such as body parts, sex and children to either be prohibited from sale (market-inalienable) or subject to regulation which limits commodification and protects personhood (limited market-inalienability). ${ }^{54}$

Thus, to be granted property in a valuable resource is not to be granted 'sole and despotic dominion' over it since exclusionary rights will be pockmarked with exceptions depending on the existence of other interests in the resource which the law is accustomed

45 H Dagan, 'Property's Structural Pluralism: On Autonomy, the Rule of Law, and the Role of Blackstonian Ownership' (2014) 3 Brigham-Kanner Property Rights Conference Journal 27.

46 Dagan (n 44) 1411.

47 Dagan (n 45) 29.

48 J W Singer, 'No Right to Exclude: Public Accommodations and Private Property' (1995) 90 Northwestern University Law Review 1283.

49 Dagan (n 45) 29-30.

50 A M Honoré, 'Ownership' in A G Guest (ed), Oxford Essays in Jurisprudence (Clarendon Press 1961) 107, 11214. W N Hohfeld, 'Some Fundamental Legal Conceptions as Applied in Judicial Reasoning' (1913) 23 Yale Law Journal 16; Dagan (n 45) 30.

51 J W Singer, Entitlement: The Paradoxes of Property (Yale University Press 2000) 7.

52 Ibid.

53 M J Radin, 'Residential Rent Control' (1986) 15 Philosophy and Public Affairs 350.

54 M J Radin, 'Market-inalienability’ (1987) 100 Harvard Law Journal 1849. 
to protecting. ${ }^{55}$ For example, the availability of the trespass remedy has been limited in order to protect such non-property interests as freedom of speech, ${ }^{56}$ the welfare of migrant workers, ${ }^{57}$ and the right to peacefully picket. ${ }^{58} \mathrm{~A}$ privilege which prevents liability in trespass has been granted by the courts if a defendant has furthered an interest of such societal importance as to be entitled to protection. ${ }^{59}$ The abusive exercise of rights can be curtailed in circumstances where the landowner has suffered a mere legal and not actual injury. ${ }^{60}$ It is also well established that landowners may not arbitrarily exclude individuals from private land where this land has been opened up to the public at large by the landowner. ${ }^{61}$ The common law right to exclude can be said to be substantially qualified by a competing common law right of reasonable access to public places. ${ }^{62}$

The law is clearly accustomed to protecting bodily rights, utilising a diversity of legal doctrines such as privacy, the criminal law and torts. If we accept Dagan's view that property develops distinct institutions with different rules depending on context, there is no reason to doubt that a body-as-property institution would reflect a unique commitment to vindicating the range of values in the body that the law has traditionally protected. Given the unique nature of the body, this property institution would balance the unique interests and values that the individual and the community have in the human body.

\subsection{Property Serves communitarian VAlues}

It is inaccurate to describe property in all its forms as merely serving self-interested and individualistic values, and a further misdescription to assert that property cannot capture the relational aspects of the body: property institutions can and do facilitate cooperative relationships between individuals, and between the individual and the community. Undoubtedly, there are property institutions that are shaped along Blackstonian lines being atomistic and competitive, but in other areas property law does not allow these norms to infiltrate other social spheres and thus property relations mediate some of the most cooperative areas of human interaction. ${ }^{63}$ Entitlement sacrifices required by the law, such as restrictions on rights by eminent domain and nuisance, and use sacrifices, so

55 Singer gives the example of public accommodations law which limits the ability of owners of businesses open to the public to exclude persons from their property on an invidious basis such as race: Singer (n 51) 72-75.

56 Marsh v Alabama (1946) 326 US 501 (striking down a law against distributing religious literature in a companyowned town without the permission of the landowner).

57 State v Shack (1971) 58 NJ 297 (where the conviction of the defendants for trespass for entering onto private lands to aid migrant farmworkers was overturned as being beyond the reach of the trespass statute); cf. Harrison v Carswell [1976] 2 SCR 200 (where lawful picketers were convicted of trespass for picketing at a shopping centre).

58 Amalgamated Food Employees Union Local 590 v Logan Valley Pizza Inc 308, 88 S Ct 1601, 20 L Ed 2d 603, (where the right to picket peacefully in a privately owned shopping centre was upheld); see also Schwarz-Torrance Investment Corp v Bakery and Confectionary Workers Union, 61 Cal 2d 766, 40 Cal Rptr 233, 394 P 2d 921 (Sup, Ct 1964) 380 US 906, 85 S Ct 888, 13 L Ed 2d 794 (1964).

59 Per Laskin CJ, dissenting, in Harrison v Carswell [1976] 2 SCR 200, 209-11.

60 H C Gutteridge, 'Abuse of Rights' (1935) 5 Cambridge Law Journal 22.

61 Singer (n 48); N F Arterburn, 'The Origin and First Test of Public Calling' (1927) 75 University of Pennsylvania Law Review and American Law Register 411.

62 Per Pashman J in Uston v Resorts International Hotel, Inc 445 A2d 370, 374 (NJ 1982) (where a casino was held to have no power of exclusion of a casino patron on the basis that he was 'card-counting' as this did not violate any casino rules). See also Brooks v Chicago Downs Association 791 F 2d 512 at 519 (1986) and Marzocca v Ferone 93 NJ 509, 461 A2d 1133 (1983) which suggest that the courts will be particularly concerned to prevent arbitrary exclusions where the normal workings of the market fail to prevent such excesses.

63 Dagan (n 45) 30. 
as to ensure the historic preservation of buildings and environmental protection, are illustrative of the view that private property owners owe duties to the community at large. ${ }^{64}$

Property scholarship concerning the environment is of particular interest to those concerned with questions as to the propertisation of the body, as it has recognised that prevailing theories of property are incompatible with two essential features of environmentalism: the interconnectedness of people and their environment and the importance of the unique characteristics of each object. ${ }^{65}$ Rather than rejecting property as a means of achieving environmental goals, they seek for a new metaphor that can better account for human-human relationships, human-object relationships and the importance of the unique characteristics of an object when defining the nature of the rights and interests in it. ${ }^{66}$ When all property is regarded as a commodity and seen merely as an instrumental tool to increase value, the environment suffers and a rebalancing of property law is required with the recognition of certain lands as a separate legal category where their undeveloped status can be protected. ${ }^{67}$

The creation of such a separate category in property law would clearly be of interest to those who share the Kantian concern that human beings should never be used solely as a means only to an end, as being human is always an end in itself. ${ }^{68}$ Such a theoretical development would merely reflect that there are many categories of things, be they wilderness lands or human ova, that are not appropriately categorised as Blackstonian property, but would benefit from being included in the property system if it could be tailored to protect these unique objects.

Were this otherwise, and if the nature of property were indeed absolute, the state would be unable to adjust property rights to the public good by regulation without the payment of compensation in every case. Effectively, then, the government would only be able to regulate by purchase, effectively rendering regulation of the use of land impossible. ${ }^{69}$ In the USA, where attachment to the idea of property as Blackstonian, absolute and fundamental to individual liberty is at its strongest, the lawful exercise of the 'police power' by government may diminish the value of private land without any duty to pay compensation. ${ }^{70}$ Where the government effects a 'taking' of property for public use, this is subject to a constitutional requirement that 'just compensation' be paid to the owner. Nonetheless, a considerable range of activities have been held not to be such a

64 G S Alexander, 'The Social-obligation Norm in American Property Law'(2008) 94 Cornell Law Review 745, 773-809.

65 C A Arnold, 'The Reconstitution of Property as a Web of Interests' (2002) 26 Harvard Environmental Law Review 281.

66 Ibid 282.

67 J G Sprankling, 'The Antiwilderness Bias in American Property Law' (1996) University of Chicago Law Review 519, 586. J G Sprankling, 'An Environmental Critique of Adverse Possession' (1994) 79 Cornell Law Review 816.

68 R Johnson and A Cureton, 'Kant's Moral Philosophy' in E N Zalta (ed), The Stanford Encyclopedia of Philosophy (Fall 2017 edn) <https://plato.stanford.edu/archives/fall2017/entries/kant-moral/>.

69 Pennsylvania Coal Co v Mahon, 260 US 393, 413 (1922); Penn Central Transportation Co v New York City, 438 US 104, 124 (1978).

70 J L Sax, 'Takings and the Police Power' (1964) 74 Yale Law Journal 36; F I Michelman, 'Property, Utility and Fairness: Comments on the Ethical Foundations of "Just Compensation” Law' (1967) Harvard Law Review 1165. 
taking, including zoning ordinances, ${ }^{71}$ the abatement of nuisance, ${ }^{72}$ conservation, ${ }^{73}$ the regulation of business, ${ }^{74}$ public navigation rights, ${ }^{75}$ and the health and safety of the community. ${ }^{76} \mathrm{~A}$ 'bewildering array of rules' has developed to determine which losses are compensable takings and which are not. ${ }^{77}$ If property's nature were truly absolute, a traditional and formal legal test would have yielded consistency and precision in how these cases were decided, but this has not been the case. ${ }^{78}$

Indeed, at every stage of history in the Western world individuals risked having their property taken from them by the state. ${ }^{79}$ And A W B Simpson characterises Blackstone's description of property ('So great, moreover, is the regard of the law for private property, that it will not authorize the least violation of it; no not even for the general good of the whole community.') ${ }^{80}$ as 'possibly misleading' since there probably existed in Blackstone's time Crown powers to take property without parliamentary approval. ${ }^{81}$ Indeed, in English law there is no similar right to compensation for regulatory takings, as is mandated in US constitutional jurisprudence. ${ }^{82}$ Furthermore, Article 1 of the European Convention on Human Rights (ECHR) provides that no one shall be deprived of their possessions 'except in the public interest', a seemingly broader range of justifiable expropriations than contemplated in the US Constitution where it is the 'public use' that provides the justification. 83

\section{Property in the body}

\section{1 THE BODY AND LIMITED OWNERSHIP RIGHTS}

Recent debate regarding the appropriate legal category to assign to the body and its parts has focused on whether these materials should be the subject of a property or a statutory regime. ${ }^{84}$ In reality, if a property regime were adopted, statutes would be needed to regulate these property rights so the claim for a property regime is not an exclusive one. ${ }^{85}$ It is, of course, possible to reject a property approach and rely solely on statutory regulation, but there are disadvantages to this approach. In particular, it is impossible to anticipate all possible legal disputes that will arise when designing a statutory scheme and

71 Just v Marinette County 56 Wis 2d 7 (1972) (a zoning ordinance restricting shore-land development to prevent the degradation and deterioration that would result from uncontrolled development).

72 Gardner v Michigan, 199 US 325 (1905) (regulation of garbage disposal and control).

73 Penn Central Transportation Co et al v New York City, 438 US 104, 124 (1978) (restrictions on development of historic buildings); Just v Marinette County (n 71).

74 Such as restrictions upon prostitution: L'Hote v City of New Orleans, 177 US (1900); and alcohol Boston Beer Co $v$ Massachusetts, 97 US 25 (1878)

75 For example, imposing a navigational servitude on a once private pond that the owners had connected to the bay: Kaiser Aetna et al v Unites States 444 US 164 (1979).

76 Munn v Illinois, 94 US 113, 146 (1876) (fire regulations).

77 Michelman (n 70).

78 Judge Harlan set down such a test focusing on traditional legal concepts, such as appropriation of property interest, physical invasion and nuisance: Mugler v Kansas, 123 US 623 (1887).

79 F A Mann, ‘Outlines of a History of Expropriation' (1959) 75 Law Quarterly Review 188.

80 W Blackstone, Commentaries on the Laws of England (Clarendon Press 1765) i, 134-40.

81 A W B Simpson, 'Constitutionalizing the Right to Property: The US, England and Europe' (2008) 31 University of Hawai'i Law Review 1, 7.

82 Ibid 14-15; indeed, any analogous right is of much more limited scope: Colley $v$ Secretary of State for the Environment and Canterbury City Council (1998) 77 P \& CR 190.

83 Simpson (n 81) 19.

84 See Goold et al (n 1).

85 Herring (n 8) 228. 
there are dangers that lacunae will be left by any such regulation. As human biomaterials increase in value and advances in technology create new contexts in which such value rises, there is likely to be an increase in the number of and complexity of disputes involving human tissue. ${ }^{86}$ The advantage of a broad legal category like property is that it allows legal rules to be expressed at a high level of generality, greatly reducing the administrative costs of amending and interpreting the law. Laws that do not treat a thing as part of a broader class can be described as sui generis. Such a specialist regime risks creating regulatory gaps and also imposing high administrative costs upon lawyers and the public. ${ }^{87}$ There is also the danger in an area such as biotechnology that a suigeneris regime might be quickly overtaken by technological change to the extent that the regime is based on assumptions that are no longer valid, creating 'regulatory disconnection': i.e. where the law is still applicable and there is no legal disconnection, but it may not be appropriate to apply it to this new technology creating regulatory disconnection 88

Proponents of a property regime point to the fact that it would make available preexisting remedies in novel disputes where there would be none otherwise. ${ }^{89}$ As noted, opponents point to the dangers that the body and the person who inhabits it will be devalued by the application of a property regime to human biomaterials, potentially leading to objectification, commodification, fragmentation and expropriation of the body and its parts by the state. ${ }^{90}$ Thus, treating the body as property is rejected on the grounds that it will lead to practices that are considered by many to be objectionable, such as the sale of organs, the right to sell oneself into slavery and the right to sell sexual services. ${ }^{91}$ Such fears are as a result of the tendency to conflate more limited forms of property with full ownership and to consider all forms of property as equating with roughly the same set of rights. 92

If, however, we regard property as it is often regarded both judicially and academically, ${ }^{93}$ in terms of Antony Honorés standard incidents of ownership, property is a series of rights (as well as some duties and restrictions), such as the right to possess, the right to use, the right to manage, the right to transmissibility, and the right to derive income from the thing. ${ }^{94}$ According to Honoré, for full ownership in a thing to be recognised, one must hold most of these incidents with regard to the object of property. As with games, there is no single characteristic that all types of property share: rather, there is a network of overlapping and criss-crossing similarities. ${ }^{95}$ Furthermore, these incidents can be further characterised as being those which allow the owner to control the uses to which the property is put, and those allowing him or her to derive income from

86 I Goold and M Quigley, 'The Case for a Property Approach' in Goold et al (n 1) 246.

87 L B Moses, 'The Problems with Alternatives to Property' in Goold et al (n 1) 197, 200.

88 R Brownsword, Rights, Regulation and the Technological Revolution (Oxford University Press 2008); L B Moses, 'How to Think about Law, Regulation and Technology: Problems with “Technology" as a Regulatory Target' (2013) 5(1) Law, Innovation and Technology 1.

89 R N Nwabueze, 'Donated Organs, Property Rights and the Remedial Quagmire' (2008) Medical Law Review 201; Yearworth v North Bristol NHS Trust [2009] EWCA Civ 37; Holdich v Lothian Health Board [2013] CSOH 197; Hecht v Superior Court (Kane) (1993) 16 Cal App 4th 836, 20 Cal Rptr 2d 275.

90 Rao (n 23).

91 M Quigley, 'Property and the Body: Applying Honoré' (2007) 33 Journal of Medical Ethics 631.

92 D C Hubin, 'Human Reproductive Interests: Puzzles at the Periphery of the Property Paradigm' (2012) 29 Social Philosophy and Policy 106, 107.

93 See Yearworth v North Bristol NHS Trust [2009] QB 1.

94 A M Honoré, 'Ownership' in A G Guest (ed), Oxford Essays in Jurisprudence (Clarendon Press 1961) 107, 11214.

95 Honoré makes use of Wittgenstein's concept of family resemblance: Quigley (n 90). 
the thing. The existence of certain incidents does not imply the existence of others - e.g. I may have the power to use something but not have the power to sell it. While none of the standard incidents is necessary for ownership to be present, it is certainly possible for all of these incidents to vest in the owner, sometimes referred to as 'full-liberal ownership'. ${ }^{96}$ However, there are many forms of property which are more limited as some of the standard incidents are not present; for instance, an owner may have control rights but not income rights. ${ }^{97}$ Thus, the fact that I have the right to control a thing (such as my body) does not automatically imply that I have the right to sell it, or any part of it. Indeed, Douglas and Goold maintain that commercialisation and exploitation are not inevitable consequences of recognising property in the body as the law of property does not confer a right to use nor restrict an owner's liberty to use a thing. ${ }^{98}$ Thus, in a technical legal sense at least, the concept of property does not inevitably lead towards any of the feared outcomes since any of the standard incidents can be absent from the bundle of rights. Nonetheless, limited forms of property still meet the definition of full-liberal ownership in Honoré's scheme as long as most of these incidents are present, allowing flexibility in how we design property regimes. ${ }^{99}$ Recent legal decisions have demonstrated a cautious move towards explicit recognition of some property rights in biomaterials vesting in their source, but this recognition has been of limited property rights and has not included income rights. ${ }^{100}$ The transfer of rights may also be restricted so as to protect the non-property interests of the individual and society, and questions as to what parts of myself I may sell or gift, and to whom, are highly contested areas of academic inquiry and no consensus has developed as to what a person may do with their blood, ${ }^{101}$ organs, ${ }^{102}$ and sperm and ova, ${ }^{103}$ both before and after death. ${ }^{104}$ Implicit in these debates is that the right to fragment the body can be limited, and the extent of such limitations is where the contest lies. ${ }^{105}$ Such limited rights are consistent with a property approach as most commentators who advocate this approach to body parts do not argue for fullliberal ownership by the person of their bodies, i.e. they acknowledge that the 'owner' will not enjoy the fullest set of rights possible on the ownership spectrum. For instance, Quigley contends that having self-ownership consists in having most of the elements of ownership set down by Honoré and given inter alia that we have use and control of our

\footnotetext{
96 J W Harris, 'Who Owns My Body' (1996) Oxford Journal of Legal Studies 55.

97 Professor Harris describes such a limited form of ownership as 'mere property': Harris (n 6) 28, 360-61

98 As, in their view, the right to use is not a property right but a liberty and would exist irrespective of whether or not property rights were recognised in respect of human biomaterials: S Douglas and I Goold, 'Property in Human Biomaterials: A New Methodology (2016) 75(3) Cambridge Law Journal 478, 490-91.

99 Quigley (n 91).

100 Yearworth v North Bristol NHS Trust [2010] QB 1; Holdich v Lothian Health Board [2013] CSOH 197; Hecht v Superior Court (Kane) (n 89).

101 R M Titmuss, The Gift Relationship: From Human Blood to Social Policy (Allen \& Unwin 1970).

102 A J Cronin and D Price, 'Directed Organ Donation: Is the Donor the Owner?' (2008) 3 Clinical Ethics 127; Nwabueze (89); J S Taylor, Stakes and Kidneys: Why Markets in Human Body Parts are Morally Imperative (Routledge 2017).

103 R P Jansen, 'Sperm and Ova as Property' (1985) Journal of Medical Ethics 123; J Wall, 'The Trespasses of Property Law' (2013) Journal of Medical Ethics 1; J A Robertson, 'Egg Freezing and Egg Banking: Empowerment and Alienation in Assisted Reproduction' (2014) Journal of Law and the Biosciences 113.

104 Hecht v Superior Court (1993) 16 Cal App 4th 636; T C Voo and S Holm 'Organs as Inheritable Property' (2013) 40 Journal of Medical Ethics 57.

105 Douglas and Goold correctly caution against confusing normative questions as to whether property can or should be recognised in human biomaterials and determining the content of those rights and how they may be transferred: S Douglas and I Goold (n 98).
} 
bodies, we can be said to own them. ${ }^{106}$ While J W Harris states that every person ought to be considered the owner of his or her separated body parts, he believes that this right is limited to use and control rights and does not carry transmission powers. ${ }^{107}$

Regarding property as equivalent to the full spectrum of ownership rights has resulted in alarmist assumptions that, for example, endorsing property rights in the body is tantamount to endorsing a right to sell a body part at any time for cash, or rendering valuable body parts subject to eminent domain. ${ }^{108} \mathrm{~A}$ more realistic understanding of the richness and diversity of property rights leads instead to an appreciation of the variety of possible property regimes in human biological materials. ${ }^{109}$ Property has always been limited by the interests and rights of others, both owners and non-owners, and it is not fanciful to speculate that a property institution governing the body would be configured in such a way as to serve a plurality of commitments; in particular those non-property interests, identified by commentators such as Dagan, Joseph Singer and Radin, of personhood, aggregate welfare and social responsibility. ${ }^{110}$

In the limited ways in which the law currently recognises property in the body - in relation to human gametes, corpses and transplantable organs - the development of the law lends support to this view that property rights in the body will be limited rights, with a reconfiguration of an owner's rights if they are found to conflict with the rights of nonowners. Where property rights have been recognised or at least argued for in human body parts, their extent has been attenuated by the recognition that a grant of full-liberal ownership would negatively impact upon other interests that the law is accustomed to protecting. The trend where such an interest is identified is thus away from, and not towards, granting full-liberal ownership of body parts given the range of other interests such ownership rights potentially conflict with.

Human gametes are of note here given the variety of sensitive interests they can implicate. This stems from their potential for the creation of human life: i.e. they have genetic information in readily usable form. ${ }^{111}$ Furthermore, this potential use can be preserved for many years since the technology now exists to freeze such materials ex vivo. There have followed disputes in the courts about who can control and use such materials after the death of the testator, as well as whether the loss or destruction of these samples as a result of breach of duty is compensable. ${ }^{112}$ And, while the courts have recognised sperm as property in a number of cases, nowhere has full-liberal ownership been expressly granted to the samples' owner. Indeed, to the extent that frozen sperm samples can be described as property, such rights are severely restricted by detailed statutory regulation. ${ }^{113}$ Rights in gametes have been limited in other ways in response to a developing understanding of how granting unlimited rights of disposal in them (i.e. the right to transfer them anonymously) may harm future offspring. Until recently, seeking to know one's genetic origins only concerned a small group of people. With recent advances in artificial reproduction and also the increase in the number of non-traditional families, this group has quickly expanded, as there are many ways a child can be conceived and

106 Quigley (n 91).

107 Describing such a right as 'mere property': Harris (n 6) 360-61.

108 V D Mahoney, 'The Market for Human Tissue' (2001) 86 Virginia Law Review 163, 202.

109 Ibid.

110 Above at 294-96.

111 Jansen (103).

112 Hecht v Superior Court (n 104); Yearworth v North Bristol NHS Trust (n 100); Holdich v Lotbian Health Board (n 100).

113 Human Fertilisation and Embryology Act 1990 (UK); Yearworth v North Bristol NHS Trust (n 100). 
raised in the modern world. ${ }^{114}$ In the past, it was presumed that donor-conceived people were best served not knowing the circumstances of their conception. ${ }^{115}$ Only recently has this paternalistic approach been superseded and the interest in knowing one's biological parents is now phrased in terms of a 'right to know'. This change of attitude came as a result of personal accounts and small-scale studies that illuminated the views of donorconceived people. ${ }^{116} \mathrm{~A}$ number of consistent themes were revealed; early telling was better than late telling; where the information about the individual's conception was revealed later in life the donor-conceived person may experience negative feelings about the concealment ('It's not the conception, it's the deception that's the problem.'); donorconceived persons expressed an interest in knowing their donor personally, as well as in identifying and locating any half-siblings that might exist; finally, lack of information about the donor was a source of deep concern and frustration and of problems with identity for many donor-conceived people. ${ }^{117}$ The right to know one's origins is a feature of the broader right to ascertain and preserve one's identity, and human rights law has in recent times been called in aid of these claims. Article 8 of the ECHR protects the right to private and family life, and the right to know one's origins has been held to be included in the privacy guarantee by the European Court of Human Rights (ECtHR). ${ }^{118}$ The recent change of attitudes towards the right to know one's origins has been reflected in the case law of the ECtHR. The margin of appreciation was formerly so broad that the court upheld absolute secrecy as to the identity of a parent as permitted in French law. ${ }^{119}$ In subsequent cases, however, the margin has narrowed considerably and the court now considers that this right to know one's identity and origins belongs to the inner core of the right to respect for one's private life as guaranteed by Article 8. In cases where this right is concerned, the court will now examine the state's balancing of rights with close scrutiny. ${ }^{120}$ In addition to these protections derived from Article 8 of the ECHR, Article 8 of the Convention on the Rights of the Child expressly guarantees identity rights and Articles 17 and 18 of the International Covenant on Civil and Political Rights guarantees the right to privacy and right to birth registration, from which the right to know one's origins can be derived implicitly. ${ }^{121}$ This growing legal recognition of the fundamental importance of the right to know one's genetic parents in human rights law has led to numerous jurisdictions prohibiting or curtailing anonymous gamete donation. ${ }^{122}$ For instance, the UK, New Zealand, the Australian State of Victoria, British Columbia as well as a number of mainland European countries have banned anonymous

114 S Besson, 'Enforcing the Child's Right to Know Her Origins: Contrasting Approaches under the Convention on the Rights of the Child and the European Convention on Human Rights' (2007) International Journal of Law Policy and the Family 137, 138.

115 R Deech, 'Family Law and Genetics' (1998) 61 Modern Law Review 697.

116 E Blyth, M Crawshaw, L Frith and C Jones, 'Donor-conceived People's Views and Experiences of Their Genetic Origins: A Critical Analysis of the Research Evidence' (2012) 19 Journal of Law and Medicine 769.

117 E Blyth, 'Information on Genetic Origins in Donor-assisted Conception: Is Knowing Who You Are a Human Rights Issue?’ (2002) 5 Human Fertility 185, 187.

118 Odiévre v France, 42326/98 [2003] ECHR 86 (13 February 2003), [29].

119 Ibid.

120 Jaggi v Switzerland 58757/00 [2006] ECHR (13 July 2006), paras [37]-[38].

121 Besson (n 114) 141.

122 L Frith, 'Gamete Donation and Anonymity: The Ethical and Legal Debate' (2001) 16 Human Reproduction 818; I De Melo-Martin, 'The Ethics of Anonymous Gamete Donation: Is There a Right to Know One's Genetic Origins?' (2014) 44 Hastings Centre Report 28; A Ravelingien and G Pennings, 'The Right to Know Your Genetic Parents: From Open-identity Gamete Donation to Routine Paternity Testing' (2013) 13 American Journal of Bioethics 33. 
donation of gametes, and donors must now be identifiable to their genetic offspring. ${ }^{123}$ If one regards, as many do, sperm and eggs as property, such regulatory requirements represent a restriction on alienation enacted to secure the non-property interests of any future offspring. One may still transfer ownership (by transferring possession and the right to control and use) of the sperm sample to the Assisted Reproductive Technology clinic or donee, but there is a limit on such alienability in that it can no longer be anonymous.

A similar approach is evident in regard to common law quasi-property rights that the next-of-kin have over their relative's dead body. ${ }^{124}$ Although at common law, there is traditionally 'no property' in a corpse, the law recognised a sort of quasi-property whereby they may be, indeed are, under a duty to take possession of a corpse for the purposes of burial, and the law would protect against such an interference. ${ }^{125}$ Thus, the entitlement to possession of the corpse is severely attenuated by non-property interests: both of the deceased and the wider community. ${ }^{126}$ Granting the deceased a proper funeral is in accordance with human dignity, while public health requires the prompt disposal of the remains so as the living are not endangered by the spread of disease. ${ }^{127}$

The ongoing debate over the status of transplantable organs also illustrates the powerful reasons for limiting property rights in them. Organs aren't fully property, as they cannot be sold due to concerns about commodification. ${ }^{128}$ While they may be gifted, there are restrictions on this power that echo public accommodations cases where certain facilities, both public and private, must not discriminate on the basis of such matters as race, religion or national origin. ${ }^{129}$ Indeed, concerns as to controversial conditions relating to age, race or gender being attached to conditional donations has led to their blanket prohibition in the UK. ${ }^{130}$ Once it was clear that a power to attach conditions to donated organs could lead to interference with rights that the law has customarily protected - i.e. discrimination on prohibited grounds - policymakers acted quickly to limit the powers of the donor in gifting their organs. ${ }^{131}$

Thus, it can be seen that property institutions in human tissue are beginning to develop in ways that would be predicted by Dagan rather than Blackstone, being limited in response to potential harms caused to the non-property interests of persons other than the owner.

\subsection{The language OF Property}

There is a more nuanced objection to recognising a property regime in the body. This states that in applying the language of property and the market to the body, this rhetoric will have a detrimental effect upon important values and reduce the body to a fungible

123 De Melo-Martin (n 122) 28.

124 W Boulier, 'Sperm, Spleens and Other Valuables: The Need to Recognize Property Rights in Human Body Parts' (1995) 23 Hofstra Law Review 693, 700.

125 Ibid 709-11.

126 H Conway, 'Dead, but not Buried: Bodies, Burial and Family Conflicts' (2003) 23 Legal Studies 423, 426-27.

127 Re Blagdon Cemetery [2002] 3 WLR 603; R v Newcomb (1898) 2 CCC 255.

$128 \mathrm{~J}$ L Nelson, 'Trust and Transplants' (2005) 5 American Journal of Bioethics 26, 27.

129 J W Singer, 'We Don't Serve Your Kind Here: Public Accommodation and the Mark of Sodom' (2015) 95 Boston University Law Review 929

130 'Dobson Threatens New Law to Halt Donor "Apartheid"” The Guardian (London, 8 July 1999) <www.theguardian.com/uk/1999/jul/08/race.world>; Cronin and Price (n 102).

131 H K Consolo and S J Wigmore, 'Ethical and Legal Issues with Organ Donation and Transplantation' (2017) 35 Surgery (Oxford) 341, 345. 
commodity whose only value is its exchange value on the market. ${ }^{132}$ This objection is rooted in the fact that language and how we use it has the power to affect perceptions and shape our view as to what is important in life. ${ }^{133}$ Donna Dickenson contends that, once the body is viewed as a full-fledged commodity, it will be subject to a multitude of abuses such as the trading and trafficking of organs, the exploitation of sperm and egg donors by unscrupulous fertility clinics (what she terms 'baby shopping'), or the taking of organs, tissue and indeed bones from the dead without the necessary consent of the deceased or their family. ${ }^{134}$

The familiar counterargument to this, as set out above, is that property is often limited and we should not conflate all types of property with Blackstonian property. Nonetheless, the language used by legal regulations will not just be used by lawyers but also medical professionals, philosophers and the public at large. Some commentators contend that, while lawyers may understand that such terminology has a technical meaning, the subtleties and nuances of property institutions will not be clear to others. As language has a power of its own, they fear that the use of property language will serve to objectify and commercialise people. ${ }^{135}$ Thus, they are not attuned to the complexity of the relational model of the bundle of sticks, and describing the body as property would influence policymakers and the public to think of the body in terms leading to objectification and commercialisation. ${ }^{136}$

This objection gives too little credit to non-lawyers' intuitions about the differing meanings of property. As Professor Harris notes, we frequently invoke what he describes as 'body-ownership rhetoric' to forcefully assert our right to use our bodies as we wish, but this analogy to property in resources is not meant to be taken literally. ${ }^{137}$ Law and social norms recognise something close to full-liberal ownership in resources, but someone invoking body-ownership rhetorically is not committed to claiming the full range of use rights, income rights and transmission powers over their bodies. ${ }^{138}$ One does not have to be a lawyer to understand that a reference to 'my body' means something somewhat different than 'my pen' or 'my car', even if the rhetoric of ownership is the same. ${ }^{139}$

Indeed, there is empirical research in relation to organ donation that suggests the language of commodification is far too simple to capture everyday intuitions about the body. ${ }^{140}$ Participants demonstrated a plurality of attitudes towards the body; namely, the body as a mechanical object, the body as part of a higher order embodying the self, and the body as a hierarchy of organs constitutive of the self. In the focus groups, the authors noted that the idea of bodily self-determination - i.e. the right of a person to do what

132 M J Radin, Contested Commodities (Harvard University Press 1996) 122.

133 Mahoney (n 108) 206.

134 D Dickenson, Body Shopping: Converting Body Parts to Profit (Oneworld Publications 2008) 1-14.

135 Goold et al, 'Conclusion' in Goold et al (n 1) 281, 283. Dickenson (n 134) 6-13.

136 Goold et al, 'Conclusion' in Goold et al (n 1) 281, 283.

137 Harris (n 96) 63.

138 Ibid.

139 Ibid 62-65.

140 M Schewda and S Schicktanz, "The "Spare Parts Person"? Conceptions of the Human Body and their Implications for Public Attitudes toward Organ Donation and Organ Sale' (2009) 4 Philosophy, Ethics and Humanities in Medicine 4; S Schicktanz and M Schweda, “One Man's Trash is Another Man's Treasure": Exploring Economic and Moral Subtexts of the "Organ Shortage" Problem in Public Views on Organ Donation' (2009) 35(8) Journal of Medical Ethics 473; M Schweda and S Schicktanz, 'Public Ideas and Values Concerning the Commercialization of Organ Donation in Four European Countries' (2009) 68 Social Science and Medicine 1129. 
they wished with their body and its parts - was expressed in terms of ownership language. At first blush, this seemed to equate the human body with forms of private property where one has full-liberal ownership, but on closer examination the adoption of the language of ownership did not imply approval of commercialisation, which some viewed as impeding self-determination in corrupting a person's proper will. ${ }^{141}$ Thus, the intuitive and absolutist image of property that Thomas Grey suggests the layman holds ('to be able to use as one wishes, to sell it, give it away, leave it idle, or destroy it') does not necessarily hold true for the body. ${ }^{142}$ It is also worth noting that many of the abuses that Dickenson fears will be exacerbated by recognising property in the body have occurred throughout history; Burke and Hare would likely have been little troubled that the law recognised 'no property' in the body at the time they were carrying out their crimes. ${ }^{143}$

In addition, it cannot be assumed that the intrinsic value of certain goods will necessarily be diminished by assigning them a value in the market. ${ }^{144}$ Markets in goods are not limited to fungible commodities such as shares and negotiable instruments, but also things whose value cannot be fully captured in monetary terms such as artworks, rare musical instruments, and tickets to highly anticipated sporting events. Such items clearly have non-economic value to their owners and experience in exchanging such nonfungible goods suggests that market language would necessarily lead to us forgetting the non-economic value of human tissue and organs. ${ }^{145}$ Of course, law has an expressive function and when evaluating a legal rule we may question whether it appropriately values an event, group or practice. ${ }^{146}$ If the law inappropriately values something it may tilt social norms in the wrong direction. However, law sometimes has negligible value effect on social norms. Cass Sunstein contends that legal provisions for market exchange of intrinsic goods which are valued for reasons other than use need not affect social valuations of their intrinsic worth. ${ }^{147}$ While there is a lack of evidence that human beings cannot comprehend the diverse ways in which the human body and its parts are valued, there are many examples, some set out above, of markets in goods whose value is not limited to their commercial use. ${ }^{148}$ In light of the above, the current practice of permitting numerous transfers of property rights and market exchanges to continue, while limiting the application of the language of property and markets to such exchanges, must be called into question as leading to unscrutinised market activity. ${ }^{149}$ For example, donations of tissue and organs are often framed in the language of gift, obscuring the fact that no property can vest in the source of such materials. Such altruistic (and thus non-market) discourse also obscures the fact that 'gifted' human tissue is, as a matter of course, exploited and commercialised for private gain by medical researchers, further damaging the relationship of trust between medical professionals and the public. ${ }^{150}$

141 Schewda and Schicktanz, 'Spare Parts Person' (n 140).

142 T C Grey, 'The Disintegration of Property' (1980) Nomos XXII: Property 69.

143 O D Edwards, Burke and Hare (3rd edn, Birlinn 2014).

144 C R Sunstein, 'Incommensurability and Valuation in Law' (1994) 92 Michigan Law Review 779, 822.

145 Mahoney (n 108) 207.

146 Sunstein (n 144) 820-24; C R Sunstein, 'On the Expressive Function of Law' (1996) 144 University of Pennsylvania Law Review 2021.

147 Sunstein (n 144) 822.

148 Mahoney (n 108) 207.

149 Ibid 209.

$150 \mathrm{~J}$ K Mason and G T Laurie, 'Consent or Property? Dealing with the Body and its Parts in the Shadow of Bristol and Alder Hey’ (2001) 64 Modern Law Review 710, 723-28. 


\subsection{PROPERTY CAN PROTECT SOCIAL AND COMMUNITY INTERESTS IN THE BODY}

A further difficulty with regarding property as always synonymous with full-liberal ownership is that this simplification conflates all types of property with private property: i.e. it ignores the types of property that are communal. At times, one would be forgiven for forgetting that private property is but one factor, albeit a major one, in the overall system of resource management. But, even in capitalist economies, many valuable resources are not in private ownership, with other forms of property ranging from open access resources to differing forms of limited commons arrangements such as a pasture shared by villagers or a common area in a condominium, all of which have their own governing rules. ${ }^{151}$

Some commentators contend that human bodily materials should be considered as belonging to the community rather than the individual. For instance, Radhika Rao considers that the dead, and by extension their organs, might constitute communal property. Any individual rights thus granted over the material would be by way of stewardship and would have to be exercised for the benefit of the entire community, something akin to the public trust. ${ }^{152}$ Professor Harris contends that genetic information should belong to the entire community, ${ }^{153}$ and there are those who argue that indigenous people's genetic heritage should be protected by some form of ownership. ${ }^{154}$ One could, of course, opt to protect such communal and public interests in these materials by legal means other than property. Nevertheless, to dismiss property in favour of statutory regulation is to lose the benefit of pre-existing legal tools for protecting and managing communal interests in valuable resources where regulations are not working.

For example, when one considers the ethical difficulties in securing consent to the future use of one's tissue in research, property may provide an answer. It may be difficult, if not impossible, to foresee the types of research that the tissue will be utilised for in the future. The researcher must then decide to seek a fresh consent in every case, an enormously costly and impractical exercise, or, as became the practice, secure a broad and effectively open-ended consent to any future use of the tissue at the time of its donation. ${ }^{155}$ The donor's interests in the use of their material is supposed to be protected by this consent, but as the breadth of these consents has increased so too have ethical questions as to how meaningful they really are. ${ }^{156}$ There is a further difficulty with this regime. By researchers encouraging donation of such material (and employing the language of gift) and then excluding donors from any meaningful input into what is done with them and the type of research they are used for, public trust in the process is undermined. ${ }^{157}$

151 R C Ellickson, 'Two Cheers for the Bundle-of-Sticks: Three Cheers for Merrill and Smith' (2011) 8 Economics Journal Watch 215, 219-20; L A Fennell, 'Lumpy Property' (2012) 160 University of Pennsylvania Law Review 1955.

152 Rao (n 23) 450.

153 Harris (n 96).

154 D Harry and L A M Kaneche, 'Asserting Tribal Sovereignty over Cultural Property: Moving towards Protection of Genetic Material and Indigenous Knowledge' (2006) 5 Seattle Journal of Social Justice 27.

155 D E Winickoff and R N Winickoff, 'The Charitable Trust as a Model for Genomic Biobanks' (2003) 349 New England Journal of Medicine 1180.

156 B Hofmann, 'Broadening Consent and Diluting Ethics?' (2008) 35 Journal of Medical Ethics 125.

157 G Laurie, Genetic Privacy: A Challenge to Medico-Legal Norms (Cambridge University Press 2002) 263; Washington v Catalona 437 F Supp 2d (ED Mo 2006). 
Until recently, scholarship on the governance of biobanks ignored property and focused on consent, Institutional Review Boards and privacy. ${ }^{158}$ Rather than tinkering with the regulatory requirements, one of the most sensible solutions advocates that biobanks be based on a new form of agreement between the medical institution, the researcher and the donor community. These agreements would utilise property law to vindicate the donor community's interests by adopting the charitable trust model. ${ }^{159}$ A charitable trust with the public as the ultimate beneficiary fully accords with altruistic expectations when gifting tissue, and the donor group can act in an advisory capacity in the governance of the trust. Under the trust agreement, the donor/settlor formally transfers any property interest in his or her tissue to the trust and appoints a trustee of the property who then has a duty to manage the material for the benefit of an identified beneficiary, which in this case would be the general public. ${ }^{160}$ The adoption of a trust model has the potential to encourage donor participation in research governance, as well as encourage research that will benefit the public. ${ }^{161}$ For example, UK Biobank has adopted a variation of this model and has been established as a non-profit entity with a charitable purpose: to build a major resource that can support medical research aimed at the prevention, diagnosis and treatment of illness throughout society. Its Board of Directors is obligated under UK charity law to manage the organisation in accordance with this charitable purpose. ${ }^{162}$ Although the proper governance arrangements for biobanks is still hotly contested in the literature, the adoption of a charitable model of institutional governance allows for a form of stewardship that honours the charitable intent of the donors, protects against insolvency, promotes research and respects the dignitary interest of donors. ${ }^{163}$ Thus, property law can facilitate cooperative engagement between the various stakeholders in human biobanks, allowing their interests to be balanced flexibly with due regard to the interests of the donors, as well as tailoring incentives to ensure the material is used to perform research that will benefit the public at large.

A property regime may also provide solutions in the developing world where there is a growing recognition of the need to protect indigenous peoples from exploitation by the Western biotechnology industry. Native peoples have numerous concerns in relation to medical and genetic research. First, they worry that data from such studies will be used in a way that supports theories that conflict with theories about the origin and identity of the group. Secondly, there is a pervasive belief that bodily substances contain something of the essence of the individual even after removal from the body, and thus there are concerns about the possible mistreatment of such material by researchers. ${ }^{164}$ There are also the fears, not unique to tribal peoples, that in a small tribal group the genetic information of one individual may implicate others with the attendant privacy issues and, furthermore, that the material will be exploited for material gain by the researchers

158 D E Winickoff, 'Partnership in UK Biobank: A Third Way for Genomic Property?' (2007) Journal of Law, Medicine and Ethics 440.

159 Winickoff and Winickoff (n 155) 1180-84.

160 Ibid 1183.

161 Ibid.

162 Winickoff (n 158) 443.

163 Ibid 445. A Boggio, 'Charitable Trusts and Human Research Genetic Databases: The Way Forward?' (2005) 1 Genomics, Society and Policy 41; D W Winickoff and L B Neumann, "Towards a Social Contract for Genomics: Property and the Public in the "Biotrust" Model' (2005) 1 Genomics, Society and Policy 8.

164 R Tsosie, 'Cultural Challenges to Biotechnology: Native American Genetic Resources and the Concept of Cultural Harm' (2007) Journal of Law, Medicine and Ethics 396, 406. 
leaving the tribe no right to share in the profits. ${ }^{165}$ Legal recognition that a tribe's DNA forms its communal or cultural property could effectively achieve this. ${ }^{166}$

The Human Genome Diversity project seeks to characterise the genetic diversity of the world's peoples. In addition, it is attractive for biotechnology companies to research small, stable and genetically similar populations. ${ }^{167}$ There are particular issues - political, legal and social - that these projects raise when the genomes being studied are of indigenous peoples who are subject to economic and social disadvantage and discrimination. ${ }^{168}$ The majority of indigenous peoples did not develop a society where goods are individually owned and can be bought and sold without reference to the group. ${ }^{169}$ Land is often seen as belonging to the tribe, family or nation and cannot be sold unless the entire group agrees, an attitude that extends to property in human bodily materials such as DNA. While native property systems may include a 'bundle of rights' that attach to land and property, these rights are phrased in terms that indicate the duties and responsibilities that people have in relation to these properties. ${ }^{170}$ Alienability is not a central feature of these systems and it may not be possible to alienate many objects of property either within the group or to persons outside it. An individual in an indigenous culture will often not have the right to give or sell a blood sample for genetic testing without the consent of the group, or at all. ${ }^{171}$

Some commentators argue that informed consent procedures must be strengthened to protect vulnerable populations, taking account of their differing cultural traditions and disadvantages vis-à-vis the researchers they are dealing with so as to make the consent meaningful. ${ }^{172}$ In addition, both immediate and long-term economic and therapeutic benefits must flow back to the groups participating in these studies. ${ }^{173}$ But there is a contradiction here: it is arguable that the imposition of a model of 'informed consent' and 'benefit-sharing', even with the best of intentions, is to impose an individualistic and commodified model of exchange at variance with the culture of indigenous peoples. ${ }^{174}$ If it is simply wrong to commodify human materials, benefit-sharing does not change this and is more akin to 'a bribe than justice'. ${ }^{175}$ If we are to take the differing traditions of indigenous cultures seriously, there must be a recognition that there is often a strong sense that tribal DNA and biomaterials are subject to the common ownership of the group, and part of its cultural identity. ${ }^{176}$ Native title claims cannot be properly

165 As has, of course, already occurred in the West: Moore $v$ Regents of the University of California, 793 P 2d 479 (Cal 1990); Greenberg v Miami Children's Hospital, 264 F Supp 2d 1064 (SD Fla 2003).

166 D Dickenson, 'Consent, Commodification and Benefit-sharing in Genetic Research' (2004) 4 Developing World Bioethics 110.

167 See the (ultimately unsuccessful) proposal for an arrangement between the Tongan government and an American biotechnology company for access to genetic material from an isolated community: L Skene, "Sale" of DNA of People of 'Tonga' (2001) Genetics Law Monitor 7.

168 M Dobson and R Williamson, 'Indigenous Peoples and the Morality of the Human Genome Diversity Project' (1999) 25 Journal of Medical Ethics 204.

169 Ibid 205.

170 Tsosie (n 164) 398.

171 Dobson and Williamson (n 168) 205.

172 Ibid 205.

173 Ibid 204.

174 D L Dickenson and J Ferguson, 'Bioethics, Benefit Sharing and Indigenous Populations' in Tikanga Rangahau Mātauranga Tuku Iho Traditional Knowledge and Research Ethics Conference Proceedings 2004 (2005) 32.

175 Dickenson (n 166) 119.

176 Dobson and Williamson (n 168) 207; Harry and Kaneche (154). 
understood or valued unless their very different conceptions of property are understood and accounted for. ${ }^{177}$

Rather than resorting to the 'informed consent' model, based as it is on the Western individualistic idea of personal autonomy, utilising existing property mechanisms, including those related to common and cooperative ownership, would allow the development of legal tools for the protection of vulnerable populations against unauthorised takings of their shared interests in their bodies and genome and as a means to counter its appropriation and commodification by private interest. ${ }^{178}$ As tribal property is group-orientated and has aspects of collective and communal ownership, the utilisation of such legal mechanisms is particularly appropriate. In this way, the strong exclusionary protection that is a feature of property rights can be adapted not just to serve the individual but also communities, ethnic groups and societies wishing to protect their shared genetic heritage from private appropriation by third parties, as well as ensuring that any benefits that result from the use of their materials is returned to the group who donated them. ${ }^{179}$

\section{Conclusion}

That there is an objection to recognising property in the body and its parts when it is assumed that it serves such individualistic values is understandable. Nonetheless, this objection fails to consider property's complexity, its external interactions and internal structure. Nor does it acknowledge that property is often limited by the existence of nonproperty interests that the law is accustomed to protecting. This may be due in part to the fact that property's communitarian aspects and the extent to which there are social obligations inherent in property institutions have been undertheorised, a trend that is beginning to be reversed.

Property has pre-existing mechanisms for managing and protecting communal interests in valuable resources and could potentially provide a mechanism to protect the interests of individuals and communities in the use and control of their biomaterials. Concerns that a recognition of property in human body parts would lead to full-liberal ownership tend to overstate the danger. Where property rights have been recognised in body parts, they have been limited by reference to other non-property interests, and the trend has been away from and not towards full-liberal ownership. A recognition that property is a complex and multifaceted institution which can develop ownership models that are sensitive to context and the unique nature of the resource over which property rights are claimed strengthens the argument that a 'property approach' could be adopted for the regulation of human biomaterials in the future.

177 Tsosie (n 164) 397.

178 Dickenson (n 166).

179 A A Lemke, J T Wu, C Waudby, Jill Pulley, C P Somkin and S B Trinidad, 'Community Engagement in Biobanking: Experiences from the eMERGE Network' (2010) 6(3) Genomics, Society and Policy 50. 
